\title{
POTENSI DAN PROSPEK PENGEMBANGAN WISATA ALAM DANAU ANGGI GIDA
}

\section{(Potential and Development Prospect of the Anggi Gida Lake Natural Tourism)}

\author{
Ronald Dowansiba $^{1}$, Yohanes Y. Rahawarin ${ }^{1 凶}$ dan Mahmud $^{1}$ \\ Jurusan Kehutanan, Fakultas Kehutanan Universitas Papua Manokwari, Papua Barat, \\ 98314. Tlp/Fax: +62986211065. \\ ${ }^{\square}$ Penulis Korespondensi: Email: yohanis.y.rahawarin@yahoo.com \\ Diterima: 22 Jul 2017| Disetujui: 27 Agust 2017
}

\begin{abstract}
Abstrak
Penelitian ini bertujuan untuk mengidentifikasi keberadaan objek dan daya tarik wisata danau Anggi Gida dan untuk mengetahui faktor-faktor pendukung wisata alam serta sikap dan persepsi masyarakat daerah terhadap pengembangan kawasan wisata danau Anggi Gida. Metode yang digunakan yaitu metode deskriptif dengan teknik pengumpulan data secara observasi melalui wawancara. Hasil penelitian menunjukkan bahwa terdapat dua danau yaitu danau Anggi Gida dengan luas 2.500 ha dan Anggi Giji dengan luas 1.800 ha. Secara fungsi, kawasan ini memiliki peran yang demikian penting dalam upaya pelestarain flora, fauna dan keberadaan komunitas masyararakat. Secara khusus kawasan tersebut ditumbuhi oleh vegetasi pinggiran danau yang khas, diantaranya yaitu pohon (Ficus sp.), pohon arwob (Dodonea fiscosa), alang-alang danau (Imperata cylindrica). Sebagian besar responden berpersepsi positif terhadap pengembangan ODTW danau Anggi Gida dengan persentase tertinggi sebesar $81,44 \%$, sementara responden yang memilih netral sebesar $12,5 \%$ dan responden yang berpersepsi negatif (menolak) cukup kecil yaitu hanya sebesar $6,06 \%$.
\end{abstract}

Kata Kunci: Wisata alam, daya tarik wisata, persepsi, flora dan fauna, danau Anggi Gida.

\begin{abstract}
The objective of this study was to identify a number of potential objects and tourist attractions of Anggi Gida Lake and to reveal factors that supporting natural tourism as well as community's perceptions toward the development of Anggi Gidi tourism area. Method that used was descriptive though observation and semi structural discussion. The result noticed two lakes which were Anggi Gida with the area of 2,500 ha and Anggi Giji with the area of 1,800 ha. In terms of function, the area had an important control in preserving flora and fauna as well maintaining natural resources for local communities. A number of vegetation that particularly can be found in the surrounding were (Ficus sp.), arwob (Dodonea fiscosa), and cogongrass (Imperata cylindrica). Most of the respondents had a positive perception towards the development of tourist attractions in the Lake with an approximation of $81.44 \%$, while as many as $12.5 \%$ respondends was neutral. On the other hand, a small number of respondents had a negative option with only $6.06 \%$.
\end{abstract}

Keywords: Natural tourism, tourist attraction, perception, flora \& fauna, Anggi Gida Lake. 


\section{PENDAHULUAN}

Sektor pariwisata sebagai industri jasa merupakan salah satu bidang yang dapat memberikan andil cukup besar dalam pembangunan. Kegiatan pariwisata jika dikelola dengan baik dapat menjadi salah satu penyumbang pendapatan yang potensial dalam pertumbuhan ekonomi nasional maupun daerah. Pariwisata bukan hanya sebagai penghasil devisa tetapi juga dapat menyediakan lapangan kerja dari sejumlah sektor-sektor. Sumber ekonomi lain seperti perikanan, pertanian, kehutanan dan manufaktur, dapat meningkatkan upaya menjaga dan memperbaiki lingkungan. Indonesia memiliki potensi obyek dan daya tarik wisata berupa keanekaragaman hayati, keunikan dan keaslian budaya tradisional, keindahan bentang alam, bentang alam, peninggalan sejarah/budaya yang secara optimal untuk kesejahteraan masyarakat (Yuniarti dkk. 2018).

Provinsi Papua dengan kawasan hutan seluas 31,69 juta hektar memiliki sumber keanekaragaman hayati yang kaya dan jasa lingkungan yang potensial. Sumber daya ini perlu dikelola dan dimanfaatkan secara lestari bagi kesejahteraan rakyat. Di sisi lain, tanah Papua memiliki panorama yang indah dan masih alami dengan jenis obyek wisata alam yang bervariasi seperti wisata pantai, hamparan savannah yang luas, lembah-lembah, danau, kawasan ekosistem hutan hingga pegunungan (Rumbarar 2010).

Ekowisata adalah bagian dari wisata alam karena istilah ekowisata dapat diartikan sebagai bentuk perjalanan oleh para wisatawan ke daerah terpencil dengan tujuan menikmati dan mempelajari mengenai alam, sejarah dan budaya disuatu daerah dimana pola wisatanya membantu ekonomi masyarakat lokal dan mendukung pelestarian alam (Dirjen Parawisata 1995).

Pengertian tentang ekowisata mengalami perkembangan dari waktu ke waktu. Namun pada hakekatnya, pengertian ekowisata adalah suatu bentuk wisata yang bertanggungjawab terhadap kelestarian area yang masih alami (natural area), memberi manfaat secara ekonomi dan mempertahankan keutuhan budaya bagi masyarakat setempat. Atas dasar pengertian ini, bentuk ekowisata pada dasarnya merupakan bentuk gerakan konservasi yang dilakukan oleh penduduk. Ekowisata menitik beratkan pada tiga hal utama yaitu keberlangsungan alam atau ekologi, memberikan manfaat ekonomi, dan secara psikologis dapat diterima dalam kehidupan sosial masyarakat (Fandeli 2000).

Ekowisata sebagai bagian dari konsep pengembangan pariwisata telah mengalami kemajuan dengan semakin banyaknya peminat jenis wisata yang berbasis pada kelestarian lingkungan, sehingga dalam pengembangan destinasi wisata alam didapatkan hubungan timbal balik yang saling menguntungkan antara manusia sebagai makhluk yang menikmati alam dalam kegiatannya dengan alam yang terlestarikan secara baik. Ekowisata merupakan perjalanan wisata ke suatu lingkungan baik alam yang alami maupun buatan serta budaya yang ada yang 
bersifat informatif dan partisipatif yang bertujuan untuk menjamin kelestarian alam dan sosial-budaya (Fandeli 2000).

Kabupaten Pegunungan Arfak danau Anggi Gida (danau perempuan) merupakan daerah otonom baru yang merupakan pemekaran dari kabupeten induk manokwari dengan karakteristik alam dan bentang lahan yang unik dan secara umum wilayah ini termasuk dalam kawasan konservasi Cagar Alam Pegunungan Arfak dengan luas mencapai 68.325 Ha dengan ketinggian mencapai 2.940 meter di atas permukaan laut (mdpl). Salah satu kawasan yang memiliki daya tarik wisata adalah danau Anggi Gida yang berada pada wilayah ketinggian (Salosa dkk. 2014).

Tujuan penelitian ini adalah untuk mengidentifikasi keberadaan objek dan daya tarik wisata (ODTW) Danau Anggi Gida dan untuk mengetahui faktor-faktor pendukung wisata alam Danau Anggi Gida, sikap serta persepsi masyarakat daerah terhadap pengembangan danau Anggi Gida. Selain itu untuk melihat dukungan pemerintah daerah (PEMDA) serta masyarakat dalam rencana pengembangan wisata alam di danau Anggi Gida.

\section{METODE PENELITIAN}

\section{Tempat, Waktu dan Metode}

Penelitian ini berlokasi di danau Anggi Gida, Kabupaten Pegunungan Arfak yang dilakukan pada awal tahun 2015 dengan menggunakan metode deskriptif. Sementara teknik pengumpulan data yang digunakan yaitu dengan teknik observasi serta wawancara semi struktural.

\section{Pelaksanaan Penelitian}

\section{Penentuan responden}

Penentuan responden dilakukan secara porposif atau sengaja dengan mengajukan pertanyaan atau wawancara kepada responden (berdasarkan daftar pertanyaan yang dibuat pada quisioner). Responden terdiri dari responden umum dan responden kunci. Responden umum adalah masyarakat sekitar Danau Anggi Gida, dan responden kunci adalah orang yang dianggap lebih banyak mengetahui tentang keberadaan ODTW di Danau Anggi Gida Kabupaten Pegunungan Arfak. Responden kunci berasal dari tokoh masyarakat, tokoh adat, dan aparat pemerintahan. Sehingga berdasarkan hasil wawancara yang dilakukan menggunakan panduan pertanyaan (quisioner) maka di peroleh responden umum dengan jumlah 36 responden dari keempat kampung yang telah disampling. Kemudian responden kunci dengan jumlah 8 responden dari 4 kampung yang disampling, Sehingga total responden yang di wawancarai adalah 44 responden yang terdiri dari 4 kampung yang disampling.

\section{Pengumpulan data}

Data yang dikumpulkan terdiri dari data primer dan data sekunder. Data primer diperoleh dengan melakukan pengamatan langsung di lokasi penelitian dan melakukan wawancara serta dokumentasi gambar pengamatan dan dokumentasi dilakukan terhadap ODTW, sedangkan wawancara kepada responden kunci untuk mendapatkan informasi 
mengenai keadaan umum wilayah, kondisi masyarakat, serta dukungan pemerintah dalam pengembangan wisata alam di lokasi penelitaan. Wawancara menggunakan panduan pertanyaan (quisioner) dan bersifat terbuka, yaitu responden di berikan keleluasaan untuk menjelaskannya sendiri tanpa harus berpatokan pada quisioner. Data sekunder di peroleh dengan cara pencatatan melalui studi dan telaah pustaka atas laporan kegiatan, peraturan, hasil-hasil penelitian dari instansi terkait dengan topik penelitian yang dilakukan.

\section{Pengolahan dan Analisi Data}

Data yang diperoleh diolah secara tabulasi dan analisis melalui gambar/foto yang selanjutnya diuraikan terkait ODTW, kondisi aksesibilitas, sarana prasarana, sikap dan presepsi masyarakat serta dukungan pemerintah dalam pengembangan ODTW. Untuk mengembangkan objek dan daya tarik wisata dari Danau Anggi Gida, maka perlu juga mendapatkan persepsi dan sikap masyarakat, sehingga untuk itu, responden yang di ambil sebesar 10\% dari total kepala keluarga yang ada.

\section{HASIL DAN PEMBAHASAN}

\section{Potensi ODTW Danau Anggi Gida}

Danau Anggi Gida merupakan suatu tempat wisata alam yang sangat menarik, yang mana memiliki keindahan visual bentang lahan dan tekstur lansekap kawasan. Namun hingga saat ini belum banyak pengunjung yang berkunjung ke kawasan ini dikarenakan jarak tempuh yang cukup jauh dan aksesibilitas dan infrastruktur yang belum memadai.
Wilayah Pengunungan Arfak berada pada ketinggian $2000 \mathrm{~m}$ dpl dengan terdapatnya dua danau, yaitu Danau Anggi Gida (2.500 ha) dan Anggi Giji (1.800 ha). Secara fungsi, kawasan ini memiliki peran yang demikian penting dalam upaya pelestarain flora, fauna dan keberadaan komunitas masyararakat. Diperkirakan pada kawasan ini terdapat ribuan jenis tumbuhan anggrek dan legenda ikan Houn (sejenis belut) di dua danau yang diapit oleh sebuah perbukitan firdaus bernama Bukit Kobrey. Keberadaan goa-goa kecil, termasuk goa yang kedalamannya mencapai 2000 meter juga masih berada di sekitar lokasi pegunugan Arfak dengan keunikan dan kekhususannya. Berdasarkan hasil penelitian, teridentifikasi beberapa potensi objek dan daya tarik wisata alam yang selanjutnya diuraikan sebagai berikut.

\section{Panorama Danau Anggi Gida}

Danau Anggi Gida terletak pada Distrik Anggi Gida, tepatnya kawasan ini masuk dalam wilayah administratif Kampung Tombrok. Danau Anggi Gida merupakan suatu relief alamiah berupa lekukan pegunungan dengan panorama danau yang indah. Sebagian dari kawasan ini merupakan hamparan rumput yang luas. Bila berada pada kawasan ini kita dapat menikmati pemandangan danau yang indah, sebagian besar kawasan danau Anggi Gida tidak ditumbuhi pohon tetapi merupakan hamparan rumput yang ditumbuhi jenis tumbuhan paku-pakuan, pohon-pohon Dodonea fiscosa yang tumbuhnya tidak beraturan dan berukuran kecil. Selain itu air danau yang biru dan tenang serta dihiasi oleh tebing-tebing curam di sisi gunung yang pada akhirnya bertemu dengan pesisir danau pasir putih 
dan warna biru danau tentu akan memanjakan mata setiap wisatawan yang berkunjung ke kawasan ini. Aktifitas

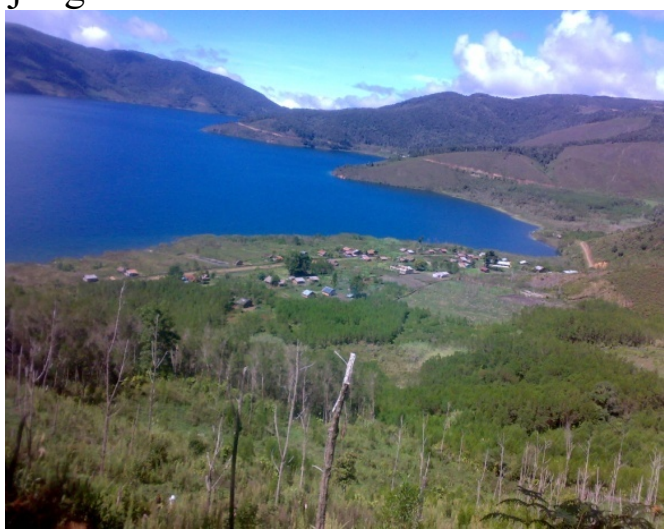

Gambar 1. Panorama lansekap kawasan tepian danau Anggi Gida dan hamparan tubuh airnya yang memukau.

\section{Aktivitas Masyarakat Anggi Gida}

Dalam konteks ekonomi masyarakat di Kampung Anggi Gida, dominan masyarakatnya berprofesi sebagai petani dengan rutinitas hariannya yakni berkebun, dan sebagia lagi melakukan kegiatan berburu dan memancing. kegiatan ini dilakukan untuk memenuhi kebutuhan rumah tangga sehari-hari baik untuk dikonsumsi sendiri dan juga dijual ke pasar untuk memenuhi kebutuhan lainnya. Hasil kebun yang ditanam antara lain daun bawang, wortel, kol, sawi, kacang panjang, dan kacang buncis. Sementara hasil buruan yang biasa diperoleh oleh masyarakat Kampung wisata yang dapat dilakukan di kawasan ini yaitu pendakian dan tracking.

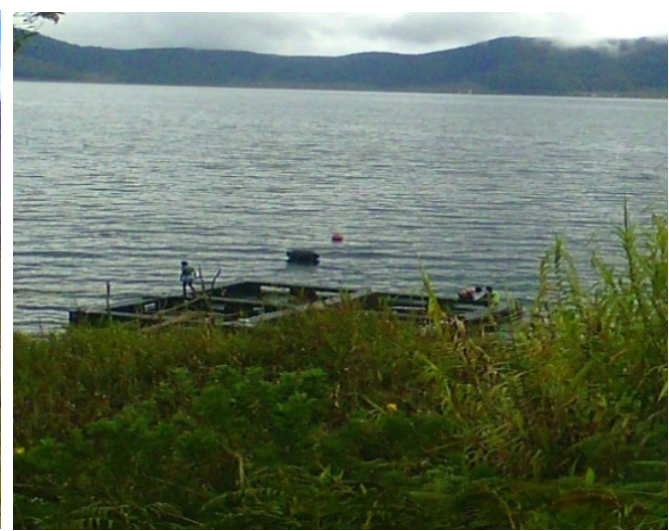

Anggi Gida adalah babi hutan, rusa, kuskus, tikus tanah, dan beberapa jenis burung. Selain itu hasil pancing yang dilakukan di pesisir danau biasanya ikan mas, dan mujair.

\section{Potensi Flora dan Fauna}

Kawasan di sekitar Danau Anggi juga memiliki potensi sumberdaya alam biotik yang turut menunjang keindahan alam pada kawasan ini. Pada kaki gunung Kobrey terdapat hutan alam yang memiliki potensi flora dan fauna yang turut menunjang wisata alam pada kawasan ini. Pada umumnya flora yang terdapat di sekitar kawasan Danau Anggi Gida dapat dilihat pada Tabel 1. 
Tabel 1. Potensi flora di kawasan sekitar danau Anggi Gida

\begin{tabular}{|c|c|c|c|}
\hline $\begin{array}{c}\text { Kelompok } \\
\text { Vegetasi }\end{array}$ & $\begin{array}{c}\text { Nama Daerah } \\
\text { (Sougb) }\end{array}$ & Nama Dagang & Nama Ilmiah \\
\hline \multirow[t]{16}{*}{ Pohon } & Sustara & Akasia & Acacia mangium \\
\hline & Jujub & Beringin & Ficus sp \\
\hline & Arwob & & Dodonea fiscosa \\
\hline & Sitga & Pulai & Alstonia scholaris \\
\hline & Igremaga & Pandan & Pandanus sp. \\
\hline & Sisra & Cemara & Casuarina sp. \\
\hline & Irga meh & Palem kipas & Livistonia $\mathrm{sp}$. \\
\hline & Kekeba & Bambu & Bamboosa sp. \\
\hline & Sinigo & Kasuari & Casuarina $\mathrm{sp}$ \\
\hline & Kowi & Damar & Agathis labilaldieri \\
\hline & Mejirga & Podokarpus & Podocapus amara \\
\hline & Kowi & Arokaria & Araucaria cuminghami \\
\hline & Idebob & Genemo & Gnentum gnemo L. \\
\hline & Adoriga & Buah roda & Ficus sp. \\
\hline & Rabey & Markisa ungu & Passiflora edulis \\
\hline & Ijaub & Pinang hutan & Areca cathecu \\
\hline \multirow[t]{5}{*}{ Rumput- rumputan } & Hugera & Kumis kucing & Orthosiphon aristatus \\
\hline & Aromogmoc & Putri malu & Mimosa pudica \\
\hline & Guhun & Alang alang & Imperata cylindrica \\
\hline & Humaga & Gelegah & Sacharum spontaneum \\
\hline & Aremedmeda & Rumput tekik & Cyperus rotundus \\
\hline \multirow[t]{4}{*}{ Tanaman Hias } & Agok & angrek & Dendrobium sp \\
\hline & Agok & Anggrek hitam & Coelegyne pandurata \\
\hline & Agok & Anggrek tanah & Sphatoglottis pricata \\
\hline & Sisra & Kantong semar & Nethentes sp. \\
\hline Tanaman & Bahaugb & Bahaugb & Bahaugb \\
\hline \multirow[t]{21}{*}{ Budidaya } & Doub & Doub & Doub \\
\hline & Bawan meh & Bawan meh & Bawan meh \\
\hline & Bejak & Bejak & Bejak \\
\hline & duromoub & duromoub & duromoub \\
\hline & Sungebey & Sungebey & Sungebey \\
\hline & $\mathrm{Ub}$ & $\mathrm{Ub}$ & $\mathrm{Ub}$ \\
\hline & Dohuwi & Jambu & Sisgium sp. \\
\hline & Jodi & Jeruk manis & Citrus sinensis \\
\hline & Junjij & Jeruk bali & Citrus maxima merr. \\
\hline & Apokat & Alfokat & Parsea americana \\
\hline & Rabey & Markisakenyol & Passiflora lingularis \\
\hline & Gongoro & Nanas & Ananas comosus \\
\hline & Ahoy & Nangka & Artocarpus integra \\
\hline & Nej & Pisang & Musa paradisiaca \\
\hline & Merij & Kunyit & Curcuma domestica \\
\hline & Merij & Lengkuas & Alpinia galangal \\
\hline & Senyemerah & Rica & Capsicum annum \\
\hline & Merij & Serei & Andropogon nardus \\
\hline & Aiswai & Singkong & Manihot utilisima \\
\hline & Tram & jagung & Zea mays \\
\hline & Aube & Ubi jalar & Ipomea batatas \\
\hline
\end{tabular}


Secara khusus, di sekitar danau ini ditumbuhi oleh vegetasi pinggiran danau yang khas, diantaranya yaitu pohon (ficus sp.), pohon arwob (Dodonea fiscosa), alang-alang danau (Imperata cylindrica).
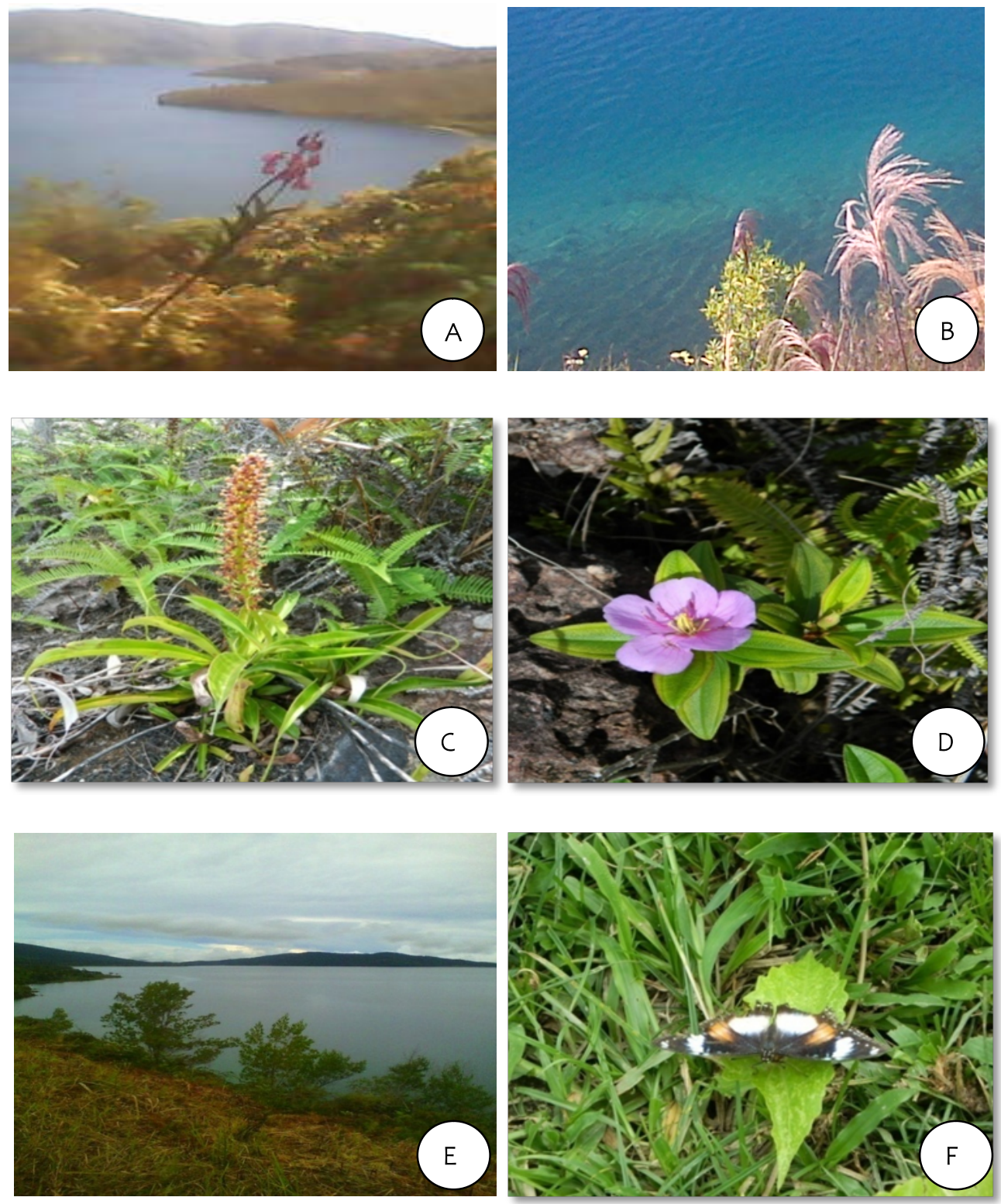

Gambar 2. Potensi bentang lahan, vegetasi dan fauna yang ditemui di sekitar kawasan danau Anggi Gidi; A) jenis angrek (Dendrobium sp.), B) jenis Gelegah (Sacharum spontaneum), C) jenis kantung semar (Nephentes sp.), D) jenis bunga tanah (Melastoma candidum), E) jenis arwob (Dodonea fiscosa) dan alang-alang (Imperata cylindrica) di pingir danau, dan F) jenis kupu-kupu (Hypolimnas bolina). 
Selain memiliki keragaman flora, kawasan ini juga memiliki keragaman fauna yang cukup tinggi. Berdasarkan hasil penelitian kawasan Danau Anggi Gida memiliki beragam jenis fauna sebagai berikut: Kakatua putih (Cacatua alba), Nuri (Eclectus sp.), Taun-taun (Rhinoceros rangkong), Elang coklat (Accipiter vasciatu), Pintar (Anbryornis inornatus), Cendarawasih (Paradisea sp.), Kupu-kupu sayap burung (Ornithoptera arfakenssi) dan beberapa jenis mamalia dan hewan perairan.

Selain itu, masyarakat yang berkunjung ke Danau Anggi Gida selain menikmati panorama kawasan ini mereka juga dapat menikmati kegiatan menyelam dan mencari ikan serta berburu satwa liar.

\section{Aksesibilitas dan Sarana Prasarana}

\section{Aksesibilitas}

Kawasan danau Anggi Gida dapat dijangkau dengan menggunakan kendaraan baik roda 4 (empat) maupun roda 2 (dua) dengan waktu tempuh kurang lebih \pm 4 jam dari kota Manokwari dan kurang lebih 2-3 jam dari Kabupaten Pegunungan Arfak. Selain itu kawasan ini juga dapat diakses dari Kabupaten Manokwari Selatan karena letaknya dipesisir danau dan Kabupaten Manokwari karena pada kawasan ini terlintas jalan trans Manokwari-Arfak. Dari Kabupaten Pegunungan Arfak, khususnya masyarakat dari Kampung Gejah dan Tuabyam dapat menjangkau Danau Anggi Gida menggunakan perahu tempel (jonson) dengan waktu tempuh \pm 1 jam dan dari Kabupaten Manokwari Selatan menggunakan kendaraan baik roda 4 maupun roda 2 dengan waktu tempuh \pm 3 jam. Aksesibilitas merupakan suatu indikasi yang menyatakan mudah tidaknya suatu objek untuk dijangkau. Soekadjo (2000) menyatakan bahwa aksesibilitas merupakan syarat yang sangat penting untuk objek wisata. Tanpa dihubungkan dengan jaringan transportasi tidak mungkin suatu objek mendapat kunjungi oleh wisatawan. Objek wisata merupakan akhir perjalanan wisata dan harus mudah dicapai dan juga mudah untuk ditemukan.

\section{Sarana Prasarana Penunjang}

Menurut Burami (2013), Sarana penunjang adalah segala sesuatu yang berfungsi untuk mendukung terlaksananya tujuan wisata. Akses penunjang ke tempat wisata akan berjalan efektif jika ditunjang oleh sarana transportasi yang memadai. Tersedianya sarana prasarana pada kota tujuan wisata juga merupakan salah satu faktor penunjang pariwisata. Wisatawan yang hendak berkunjung ke Danau Anggi Gida, dalam melakukan mobilitas telah tersedia beberapa sarana dan prasarana penunjang pada Distrik Anggi Gida seperti angkutan umum, jalan, gereja, SD, SMP, puskesmas, pasar, kios-kios, MCK yang tersebar di kampung-kampung di Distrik Anggi Gida termasuk pada Kampung Tuabyam, selain itu penduduk juga menyediakan rumah-rumah bagi wisatawan yang ingin menginap. Namun sejauh ini belum dikelola secara maksimal oleh pemerintah daerah dan stakeholder terkait lainnya.

\section{Persepsi Dan Sikap Masyarakat}

Berdasarkan hasil wawancara diketahui sebanyak $81,44 \%$ responden umum yang ada di Danau Anggi Gida setuju atau berpersepsi positif terkait upaya pelestarian dan pengembangannya sebagai kawasan objek wisata. Melihat kondisi ini tentunya merupakan modal 
dasar yang baik bagi pengembangan ekowisata di masa mendatang karena adanya persetujuan dan dukungan terutama dari masyarakat setempat. Berdasarkan persepsi dari responden diketahui bahwa masyarakat di Danau Anggi Gida telah memiliki keterbukaan berfikir dan wawasan pembanguan untuk mengelola suatu potensi di daerahnya yang bernilai ekonomi. Persepsi responden dalam rencana pengembangan objek dan daya tarik wisata alam pada danau Anggi Gida dapat dilihat pada Tabel 2.

Tabel 2. Persepsi responden dalam rencana pengembangan objek dan daya tarik wisata pada kawasan danau Anggi Gida.

\begin{tabular}{lllll}
\hline No. & Indikator & Positif & Netral & Negatif
\end{tabular}

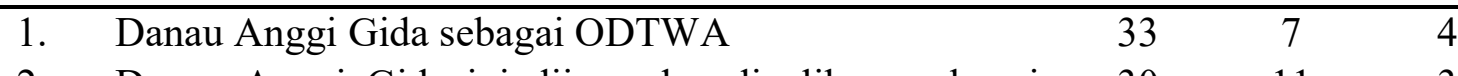

2. Danau Anggi Gida ini dijaga dan dipelihara sebagai $\begin{array}{llll}30 & 11 & 3\end{array}$ objek dan daya tarik wisata alam di Kabupaten Pegunungan Arfak

3. Melibatkan masyarakat lokal dalam pengembangan $\begin{array}{llll}40 & 4 & 0\end{array}$ ODTWA di Danau Anggi Gida

4. Memberikan keuntungan bagi masyarakat sekitar $\quad \begin{array}{llll}41 & 2 & 1\end{array}$

5. Harapan masyarakat terhadap pengembangan objek $\begin{array}{llll}40 & 2 & 2\end{array}$ wisata

6. $\begin{array}{llllll} & \text { Masyarakat mendukung pengembangan ODTWA pada } & 31 & 7 & 6\end{array}$ Danau Anggi Gida Jumlah Seluruh indikator 264

Tabel 3. Wujud persepsi responden terhadap rencana pengembangan kawasan wisata

\begin{tabular}{lcccccccc}
\hline Wujud Sikap & \multicolumn{9}{c}{ Indikator } & Jumlah & $\begin{array}{c}\text { Nisbah } \\
(\%)\end{array}$ \\
\cline { 2 - 7 } & 1 & 2 & 3 & 4 & 5 & 6 & & 81,44 \\
Positif & 33 & 30 & 40 & 41 & 40 & 31 & 215 & 12,5 \\
Netral & 7 & 11 & 4 & 2 & 2 & 7 & 33 & 6,06 \\
Negatif & 4 & 3 & 0 & 1 & 2 & 6 & 16 & \\
\hline
\end{tabular}

Dari Tabel 3, terlihat bahwa sebagian besar responden berpersepsi positif terhadap pengembangan ODTW Danau Anggi Gida. Responden yang mendukung (positif) mempunyai persentase tertinggi yaitu $81,44 \%$. Sehingga ODTW danau Anggi Gida dapat dibilang layak untuk di kembangkan karena masyarakat juga akan mendapat keuntungan dari pegelolaan ODTW Danau Anggi Gida.
Selain itu, responden yang bersifat netral mempunyai persentase sebesar $12,5 \%$ hal ini sebabkan karena masyarakat tersebut tidak menerima maupun menolak pengembangan ODTW danau Anggi Gida. Di sisi lain, responden masyarakat yang berpersepsi untuk menolak (negatif) mempunyai persentase sebesar $6,06 \%$ dari total resonden. Waskito (2014) menyatakan bahwa sikap merupakan 
kecenderungan bertindak, berekspresi terhadap suatu gagasan, situasi, masalah dan nilai tertentu.

\section{Dukungan Pemerintah Daerah}

Berdasarkan hasil wawancara terhadap responden kunci dalam hal ini pihak pemerintah yaitu pihak Badan Perencanaan dan Pembangunan Daerah (BAPPEDA) Kabupaten Pegunungan Arfak menyatakan bahwa Danau Anggi Gida telah masuk dalam catatan BAPPEDA untuk dimasukan menjadi daerah wisata strategis. Namun sampai pada saat belum ditata secara aturan dan perundangan guna mendukung konsep pembangunan wisata di daerah Danau Anggi. Salah satu kendala pengembangan ini karena masih menunggu kajian rencana tata ruang wilayah kabupaten yang masih Dallam proses kajian. Selain itu, instansi pelaksana teknis dalam hal ini Dinas Pariwisata dan Kebudayaa Kabupaten Pegunungan Arfak juga belum berdiri sendiri, karena masih tergabung pada Dinas pendidikan dan Pariwisata sehingga belum banyak yang dilakukan terkait pengembangan pariwisata daerah karena masih terfokus pada bidang pendidikan. Namun secara umum, pihak pemerintah daerah dalam hal ini BAPPEDA dan juga pejabat distrik Anggi Gida telah mendukung adanya kajian pengembangan kawasan Danau Anggi Gida sebagai daerah tujuan wisata alam.

\section{DAFTAR PUSTAKA}

Burami CDRF. 2013. Analisis pengembangan potensi wisata Bukit
Aitumeri Kabupaten Teluk Wondama.

Skripsi Sarjana Kehutanan

Universitas Negeri Papua. (Tidak Diterbitkan).

Dirjen Pariwisata. 1995. Proyek pengembangan pariwisata Sumatra Utara. CV. Miko Yova Consultan Engenering. Medan

Fandeli C. 2000. Pengertian dan konsep dasar ekowisata. Fakultas Kehutanan, Universitas Gadjah Mada. Yogyakarta.

Rumbarar FC. 2010. Potensi pengembangan ekowisata danau Habema pada kawasan Taman Nasional Lorentz Provinsi Papua. Skripsi Sarjana Kehutanan. Fakultas Kehutnan Universitas Negeri Papua (Tidak Diterbitkan).

Salosa ST, Awang SA, Suryanto P dan Purwanto RH. 2014. Hutan dalam kehidupan masyarakat Hatam di lingkungan cagar alam Pegunungan Arfak. Jurnal Manusia dan Lingkungan, Vol 21 (3): 349-355.

Waskito S. 2014. Potensi wisata alam pantai Maruni Distrik Manokwari Selatan Kabupaten Manokwari. Skripsi Sarjana Kehutanan. Fakultas Kehutanan Universitas Negeri Papua (Tidak Diterbitkan).

Yuniarti E, Soekmadi R, Arifin HS, Noorrachmat BP. 2018. Analisis potensi ekowisata Heart of Borneo di taman nasional Betung Kerihun dan Danau Sentarum Kabupaten Kapuas Hulu. Jurnal Pengelolaan Sumberdaya Alam dan Lingkungan, Vol 8 (1): 4454. 